Editor's Note: These short reviews of a recent paper in the Journal, written exclusively by graduate students or postdoctoral fellows, are intended to mimic the journal clubs that exist in your own departments or institutions. For more information on the format and purpose of the Journal Club, please see http://www.jneurosci.org/misc/ifa_features.shtml.

\title{
Growth Cone Stop Signals: Inviting to Stay or Sending Away?
}

\author{
Sharon B. Sann \\ Neuroscience Graduate Program, University of California, San Diego, La Jolla, California 92093-0357 \\ Review of Manzini et al. (http://www.jneurosci.org/cgi/content/full/26/22/6040)
}

Axons growing into a target region must select appropriate cells on which to form synapses. A signal from a target cell may invite the appropriate axon to stop extension and initiate synapse formation, whereas a nontarget cell may act as an intermediate guidepost or signal an axon to avoid approaching and move on. The cerebellar cortex provides an ideal system in which to examine such interactions because a small number of cell types make specific, stereotyped connections. Baird et al. (1992) found that cultured cerebellar granule cells specifically arrested the growth of their afferents, the pontine mossy fibers. This result was interpreted to indicate that cerebellar granule cells signal to their afferents to stop growing and form a synapse. However, in their recent Journal of Neuroscience paper, Manzini et al. (2006) demonstrate that the cultured cerebellar granule cells more closely represent immature granule cells of the external germinal layer (EGL) and that absence of these immature granule cells in vivo leads to mossy fiber axon overgrowth. Thus, the arrest signal may instead prevent axons from entering a nontarget region containing immature cells.

In the mature cerebellum, pontine mossy fibers synapse solely onto granule cells in the internal granule layer (IGL), whereas axons from the inferior olivary nucleus form climbing fiber synapses

Received July 14, 2006; revised July 28, 2006; accepted July 30, 2006.

Correspondence should be addressed to Sharon B. Sann, Neuroscience Graduate Program, University of California, San Diego, 9500 Gilman Drive MC0357, La Jolla, CA 92093-0357. E-mail: ssann@ucsd.edu.

DOI:10.1523/JNEUROSCI.2997-06.2006

Copyright $\odot$ 2006 Society for Neuroscience $\quad$ 0270-6474/06/268879-02\$15.00/0 onto Purkinje cells (Fig. 1). However, during development, some cerebellar afferents, termed combination fibers, form synaptic connections onto both granule cells and Purkinje cells. Manzini et al. [(2006), their Fig. 1 (http://www.jneurosci. org / cgi / content / full / 26 / 22 / 6040 / F1)] identified mossy fibers as the source of these combination fibers by injecting the axonal tracer DiI into the pontine nucleus of postnatal day 6 fixed mouse brains. In wild-type mice, mossy fiber combination branches extended through the Purkinje cell layer and molecular layer but did not enter the EGL. In contrast, in meander tail mutant mice lacking an EGL, mossy fiber axons extended to the pial surface [Manzini et al. (2006), their Fig. $1 F-H$ (http:// www.jneurosci.org/cgi/content/full/26/22/ $6040 / \mathrm{F} 1)]$, suggesting that the immature granule cells of the EGL normally restrict mossy fiber axons from leaving the molecular layer.

To clarify how granule cell maturity affects growth of mossy fiber axons, the authors characterized the development of granule cells in culture. Over $4 \mathrm{~d}$ in vitro (DIV), cultured granule cells transitioned from flat, dividing cells expressing Math-1, a marker of EGL cells, to mature bipolar cells identified by Zic2 and MEF2, markers of differentiated IGL granule neurons in vivo [Manzini et al. (2006), their Figs. 2 (http://www.jneurosci.org/ cgi/content/full/26/22/6040/F2) and 3 (http://www.jneurosci.org/cgi/content/ full/26/22/6040/F3)]. Pontine explants plated with 4 DIV IGL-like neurons exhibited unrestricted axon growth, but freshly plated EGL-like neurons inhibited axon growth [Manzini et al. (2006), their Fig. 4 (http://www.jneurosci.org/cgi/content/full/26/22/6040/F4)]. By immunopanning, Manzini et al. (2006) purified the EGL-like population into A2B5-positive outer, younger granule cells and TAG-1 (transient axonal glycoprotein-1)positive inner, migrating granule cells and demonstrated that the youngest A2B5positive cells were the source of the signal inhibiting pontine axon growth [Manzini et al. (2006), their Figs. 6 (http://www. jneurosci . org / cgi / content / full / 26 / 22/ 6040/F6) and 7 (http://www.jneurosci. org/cgi/content/full/26/22/6040/F7)]. Furthermore, pontine axons formed synapses, identified by colocalized synapsin 1 and PSD-95 (postsynaptic density-95) clusters, on IGL-like cells but not EGLlike cells [Manzini et al. (2006), their Fig. 5 (http://www.jneurosci.org/cgi/content/ full/26/22/6040/F5)].

Freeze-fixed granule cells but not granule cell-conditioned media or purified membrane preparations inhibited pontine axon outgrowth, suggesting that the stop signal is an extracellular matrix (ECM) component or a molecule only loosely tethered to the granule cell membrane. Additionally, heparin disrupted the inhibitory activity of EGL-like cells [Manzini et al. (2006), their Fig. 8 (http:// www.jneurosci.org/cgi/content/full/26/ $22 / 6040 / \mathrm{F} 8$ )], narrowing the candidates for the stop signal to heparin-binding proteins or guidance cues trapped by heparan sulfate proteoglycans such as Shh, fibroblast growth factors (FGFs), Wnts, Slits, and semaphorins. Because growth cones approaching immature 

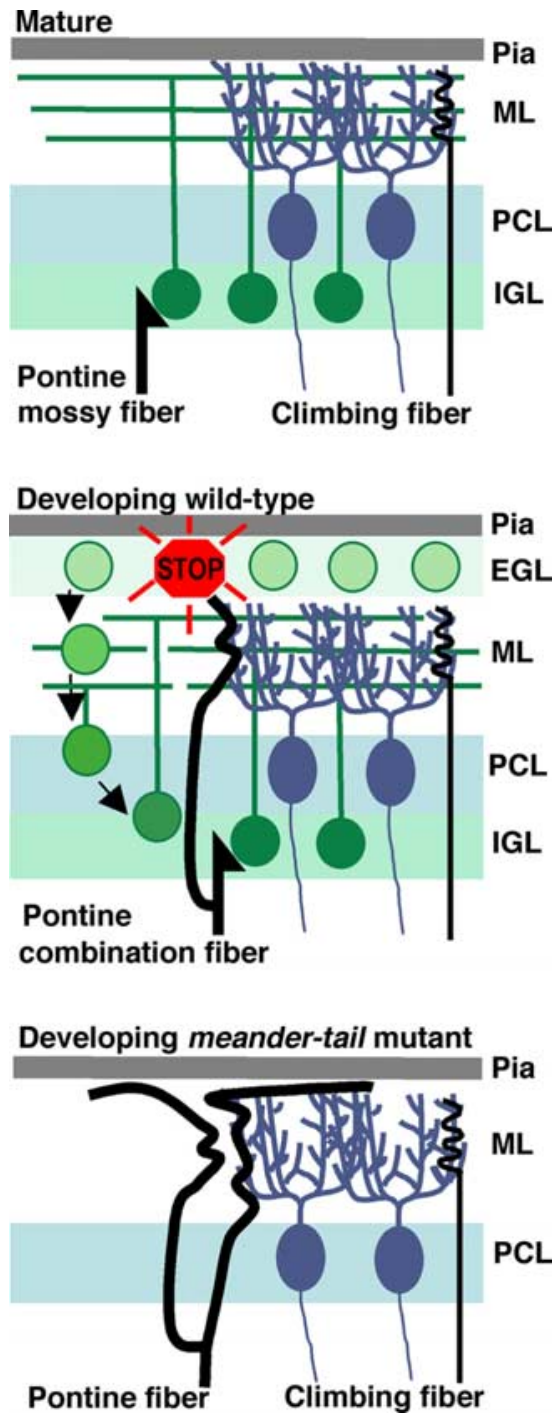

Figure 1. Pontine fiber projections in the cerebellar cortex of mature, developing wild-type, and developing meander tail mutant mice. In the mature cerebellar cortex, pontine mossy fibers synapse onto granule cells of the internal granule layer. During development, pontine axons send transient branches, termed combination fibers, into the Purkinje cell layer (PCL) and molecular layer (ML). The branches do not extend beyond the ML because of a stop signal from immature granule cells of the external germinal layer. In meander tail mutant mice, which lack granule cells, pontine fibers extend past the ML.

EGL-like cells do not show signs of collapse [Manzini et al. (2006), their supple- mental Fig. 2 (http://www.jneurosci.org/ content/vol26/issue22/images/data/6040/ DC1/Suppl2.gif); Baird et al., 1992], the authors suggest that collapse-inducing Slits and semaphorins are not the signal. Rather, the authors favor pursuing cerebellar ECM components, FGFs, and Wnts as the source of the stop signal. Indeed, the Wnt 5a-Ryk signaling pathway repulsively sends axons out of the corpus callosum and into the intermediate zone after midline crossing (Keeble et al., 2006), and the ECM molecule laminin $\beta 2$ serves as a stop signal to arrest motor neuron outgrowth (Porter et al., 1995). In addition to the role of extracellular ligands, early activity may be a key player in the proper arrest of mossy fiber axon outgrowth, as the stop signal requires activation of NMDA receptors (Baird et al., 1996).

Baird et al. (1992) reported that pontine mossy fiber arrest occurs on contact with granule cells in young cultures, whereas Manzini et al. (2006) report that mossy fiber axons avoid the flat granule cells of the same age. This apparent discrepancy may be resolved if there are two separate, maturation-dependent stop signals and by the fact that the cultures contain a mixed population of cells [Manzini et al. (2006), their Figs. 2 (http://www. jneurosci.org / cgi / content / full / 26 / 22/ 6040/F2) and 3 (http://www.jneurosci. org / cgi / content / full / 26/22 / 6040 / F3)] . Early EGL-like cells may provide a stop signal for pontine mossy fibers to avoid entering an inappropriate region, whereas mature granule cells of the IGL may signal the same axons to stop and form synapses. A strong candidate for the latter signal is Wnt-7a, which contributes to mossy fiber synapse formation onto granule cells (Hall et al., 2000). These signals by the cerebellar granule cells, sending away and inviting to stay, are only two of many signals that developing mossy fibers potentially encounter.

Currently, little is known about the molecular identity of signals that restrict axons to specific layers of laminar structures within the brain. The molecules that have been identified include cell surface membrane proteins such as the homophilic molecules $\mathrm{N}$-cadherin, sidekick, and capricious (Yamagata et al., 2002; Poskanzer et al., 2003; Shinza-Kameda et al., 2006). In contrast, Manzini et al. (2006) point the way toward an ECMrelated molecule that contributes to laminar restriction of axons. Once the molecular stop signal is identified, it will be of interest to determine whether it also plays a role in the laminar organization of axons in other brain regions.

\section{References}

Baird DH, Baptista CA, Wang LC, Mason CA (1992) Specificity of a target cell-derived stop signal for afferent axonal growth. J Neurobiol 23:579-591.

Baird DH, Trenkner E, Mason CA (1996) Arrest of afferent axon extension by target neurons in vitro is regulated by the NMDA receptor. J Neurosci 16:2642-2648.

Hall AC, Lucas FR, Salinas PC (2000) Axonal remodeling and synaptic differentiation in the cerebellum is regulated by WNT-7a signaling. Cell 100:525-535.

Keeble TR, Halford MM, Seaman C, Kee N, Macheda M, Anderson RB, Stacker SA, Cooper HM (2006) The Wnt receptor Ryk is required for Wnt5a-mediated axon guidance on the contralateral side of the corpus callosum. J Neurosci 26:5840-5848.

Manzini MC, Ward MS, Zhang Q, Lieberman MD, Mason CA (2006) The stop signal revised: immature cerebellar granule neurons in the external germinal layer arrest pontine mossy fiber growth. J Neurosci 26: 6040-6051.

Porter BE, Weis J, Sanes JR (1995) A motoneuron-selective stop signal in the synaptic protein S-laminin. Neuron 14:549-559.

Poskanzer K, Needleman LA, Bozdagi O, Huntley GW (2003) N-Cadherin regulates ingrowth and laminar targeting of thalamocortical axons. J Neurosci 23:2294-2305.

Shinza-Kameda M, Etsuko T, Sakurai K, Hayashi S, Nose A (2006) Regulation of layer specific targeting by reciprocal expression of a cell adhesion molecule, Capricious. Neuron 49:205-213.

Yamagata M, Weiner JA, Sanes JR (2002) Sidekicks: synaptic adhesion molecules that promote lamina-specific connectivity in the retina. Cell 110:649-660. 